\title{
Study Up Rating Instalasi Penjernih Air dan Catu Daya Air Bersih Kota Pacitan
}

\author{
Edy Sumirman \\ Staf Pengajar Program Studi DiplomaTeknik Sipil FTSP ITS \\ Email: locong@ce.its.ac.id
}

\begin{abstract}
ABSTRAK
Pembangunan Sarana Fisik Penyediaan Air Bersih pada dasarnya merupakan salah satu upaya pemerintah untuk memenuhi kebutuhan pokok masyarakat akan ketersediaan air bersih yang memenuhi persyaratan kesehatan, baik ditinjau dari aspek kualitas maupun kuantitas secara berkesinambungan. Untuk meningkatkan pelayanan dan kualitas air bersih salah satu usaha yang akan dilaksanakan adalah Uprating Instalasi Penjernih Air dan Catu Daya Air Bersih Kota Pacitan yang memenuhi syarat serta berkualitas diperlukan perencanaan. Dalam rangka untuk memberikan pelayanan kepada masyarakat secara luas, tentunya dibutuhkan sarana dan prasarana yang sesuai dengan tingkatan hirarkinya (lokal atau regional). Salah satu prasarana yang dibutuhkan masyarakat, khususnya dibidang sanitasi adalah ketersediaan air bersih yang mencukupi dan layak konsumsi. Dengan adanya kecenderungan peningkatan tuntutan kualitas pelayanan air bersih yang ideal dan layak konsumsi sesuai dengan perkembangan pembangunan dan kebutuhan serta tuntutan kehidupan masyarakat terhadap pelayanan air bersih merupakan hal utama yang perlu dikaji dan direncanakan sesuai dengan keinginan masyarakat pengguna air bersih yang tertib, ideal dan layak konsumsi.
\end{abstract}

Kata Kunci: Up Rating Instalasi Air Bersih, Catu Daya Air

\section{PENDAhUluAN}

Pembangunan Sarana Fisik Penyediaan Air Bersih pada dasarnya merupakan salah satu upaya pemerintah untuk memenuhi kebutuhan pokok masyarakat akan ketersediaan air bersih yang memenuhi persyaratan kesehatan, baik ditinjau dari aspek kualitas maupun kuantitas secara berkesinambungan.

Untuk meningkatkan pelayanan dan kualitas air bersih salah satu usaha yang akan dilaksanakan adalah Uprating Instalasi Penjernih Air dan Catu Daya Air Bersih Kota Pacitan yang memenuhi syarat serta berkualitas diperlukan perencanaan .

Dalam rangka untuk memberikan pelayanan kepada masyarakat secara luas, tentunya dibutuhkan sarana dan prasarana yang sesuai dengan tingkatan hirarkinya (lokal atau regional). Salah satu prasarana yang dibutuhkan masyarakat, khususnya dibidang sanitasi adalah ketersediaan air bersih yang mencukupi dan layak konsumsi.

Dengan adanya kecenderungan peningkatan tuntutan kualitas pelayanan air bersih yang ideal dan layak konsumsi sesuai dengan perkembangan pembangunan dan kebutuhan serta tuntutan kehidupan masyarakat terhadap pelayanan air bersih merupakan hal utama yang perlu dikaji dan direncanakan sesuai dengan keinginan masyarakat pengguna air bersih yang tertib, ideal dan layak konsumsi.

\section{TINJ AUAN PUSTAKA}

\subsection{SUMBER PENYEDIAAN AIR}

Sumber air dalam sistem penyediaan air merupakan suatu komponen yang mutlak harus ada, karena tanpa sumber air sistem penyediaan air tidak akan berfungsi.

\subsection{STANDAR KUALITAS AIR BERSIH DAN AIR MINUM}

Air minum yang ideal seharusnya jernih, tidak berwarna, tidak berasa dan tidak berbau. Air minum juga harus tidak mengandung kuman patogen. Tidak mengandung zat kimia yang dapat mengubah fungsi tubuh, tidak dapat diterima secara estetis, dan dapat merugikan secara ekonomis. Air juga 
seharusnya tidak korosif, tidak meninggalkan endapan pada seluruh jaringan distrbusi yang ada. Atas dasar pemikiran tersebut, maka dibuat standar air minum yaitu suatu peraturan yang memberikan petunjuk tentang konsentrasi berbagai parameter yang sebaiknya diperbolehkan ada didalam air minum agar tujuan pengolahan air bersih dapat tercapai. Standar tersebut akan berbeda untuk tiap negara, tergantung pada keadaan sosio-kultural termasuk kemajuan teknologi suatu negara.

Di Indonesia standar air minum yang berlaku pertama kali dibuat pada tahun 1975, kemudian terakhir kali diperbaiki lagi melalui Keputusan Menteri Kesehatan Republik Indonesia Nomor : 907/MENKES/SK/VII/2002[1].

\subsection{PENGGUNAAN AIR SEBAGAI SUMBER AIR BAKU}

sumber air yang digunakan sebagai sumber air baku untuk air bersih / minum yang dipertimbangkan dari tiga faktor " $\mathrm{K}$ " (kuantitas, kualitas dan kontinuitas).

\subsection{PROYEKSI JUMLAH PENDUDUK DAN FASILITAS}

\subsubsection{Proyeksi J umlah Penduduk}

Data kependudukan merupakan salah satu faktor terpenting dalam proses penyusunan suatu rencana, mengingat bahwa setiap perencanaan dilakukan serta ditujukan untuk kepentingan penduduk itu sendiri. Peningkatan jumlah penduduk akan mempengaruhi peningkatan kebutuhan fasilitas termasuk peningkatan pelayanan air bersih.

Semua sistem penyediaan air bersih harus direncanakan untuk memenuhi kebutuhan masyarakat di waktu sekarang hingga beberapa tahun ke depan sesuai dengan jumlah tahun proyeksi. Maka diperlukan proses perhitungan proyeksi penduduk sebagai awal dari kegiatan perencanaan, dimana tingkat perkembangan penduduk suatu daerah dipengaruhi oleh tingkat kelahiran (nartalitas), kematian (mortalitas) serta perpindahan penduduk (migrasi).

Untuk memperoleh nilai proyeksi yang relatif akurat, maka perlu dicari terlebih dahulu nilai koefisien korelasi ( $r$ ) dari rumus-rumus proyeksi yang akan digunakan.
Rumus koefisien korelasi :

$$
r=\frac{(n x(\Sigma x y))-(\Sigma x \Sigma y)}{\left(\left(\left(n x \Sigma y^{2}\right)-(\Sigma y)^{2}\right)\left(\left(n x \Sigma x^{2}\right)-(\Sigma x)^{2}\right)\right)^{1 / 2}}
$$

Nilai koefisien korelasi yang dipakai adalah yang mendekati nilai 1, yang menggambarkan bahwa rumus yang dipakai adalah yang lebih mewakili nilai pendekatan pertumbuhan penduduk secara optimum terhadap pola pertumbuhan yang terjadi sebenarnya untuk masa yang akan datang. Ada beberapa macam persamaan yang dapat digunakan untuk melakukan perhitungan proyeksi penduduk, antara lain :

\section{a. Metode Perbandingan}

Digunakan untuk wilayah perencanaan dengan data penduduk tidak lengkap, dimana proyeksinya menggunakan daerah lain yang dianggap memiliki kondisi sosial ekonomi serta kebijakan pembangunan yang relatif sama.

b. Metode Ekstrapolasi

Meliputi :

- Metode Ekstrapolasi Grafis, dan

- Metode Ekstrapolasi Matematis, yang terdiri dari :

1. Metode Aritmatik

Metode ini umumnya dipakai apabila pertumbuhan penduduknya relatif konstan setiap tahunnya. Sehingga jika diplotkan pada grafik akan membentuk suatu garis pertumbuhan linier. Metode ini baik digunakan jika data penduduk yang dimiliki relatif pendek, dimana data waktu proyeksi yang diambil disesuaikan dengan jumlah data yang dimiliki.

Persamaan yang digunakan adalah :

$P n=P o+r . n$.

Dimana

$\mathrm{Pn}=J u m l a h$ pro penduduk pada tahun ke-n $\mathrm{Po}=$ Jumlah penduduk mula-mula

$r=J u m l a h p e r t a m b a h a n p e n d u d u k t i a p$ tahun $\mathrm{n}=$ Banyaknya tahun proyeksi

\section{Metode Geometrik}

Metode ini umumnya digunakan bila tingkat pertumbuhan penduduk naik secara berganda atau tingkat pertumbuhan populasinya berubah secara ekuivalen dengan jumlah penduduk tahun sebelumnya. 
Persamaan yang digunakan adalah :

$P n=P o(1+r)^{n}$

Dimana :

$\mathrm{Pn}=$ Jumlah penduduk pada

tahun ke-n

3. Metode Least Square (Kuadrat Minimum) Digunakan apabila garis regresi data perkembangan penduduk masa lalu menggambarkan kecenderungan garis linier, meskipun pertumbuhan penduduk tidak selalu bertambah.

Persamaan yang digunakan adalah :

$Y=a+b x$

$\mathrm{X}=$ Jumlah tambahan dari tahun dasar

$\mathrm{a}, \mathrm{b}=$ Konstanta

$a=\frac{\Sigma y \cdot \Sigma x^{2}-\Sigma x \cdot \Sigma x y}{n \cdot \Sigma x^{2}-(\Sigma x s)^{2}}$

$b=\frac{n \cdot \Sigma x y-\Sigma x \cdot \Sigma y}{n \cdot \Sigma x^{2}-(\Sigma x)^{2}}$

$\mathrm{n}=$ Jumlah data

Adapun faktor-faktor yang mempengaruhi ketelitian proyeksi penduduk, antara lain:

- Jumlah populasi penduduk dalam suatu area.

- Kecepatan pertambahan penduduk, dimana kecepatan pertambahan penduduk tinggi akan mengurangi ketelitian proyeksi.

- Kurun waktu proyeksi.

\subsubsection{Proyeksi Fasilitas}

Dalam menetukan kebutuhan air bersih yang berpengaruh terhadap perencanaan instalasi juga harus memperhitungkan keberadaan fasilitas umum yang ada sekarang serta perkembangannya pada daerah perencanaan[2].

Adapun faktor-faktor yang mempengaruhi pertambahan fasilitas adalah :

- Pertambahan penduduk

- Jenis fasilitas

- Perluasan fasilitas yang ada

- Perkembangan sosial ekonomi.

Yang termasuk fasilitas umum dalam kaitannya dengan perencanaan unit pengolahan air bersih adalah :

- Tempat ibadah

- Perkantoran
- Pendidikan

- Sarana Kesehatan

- Komersial

- Industri

- Fasilitas umum yang lain

\subsection{PROYEKSI KEBUTUHAN AIR BERSIH} 2.5.1 Kebutuhan Air Domestik

Pemenuhan kebutuhan air untuk domestik memiliki bagian terbesar dalam kebutuhan dasar perencanaan unit pengolahan. Faktor kebiasaan, pola dan tingkat kehidupan yang didukung oleh adanya perkembangan sosial ekonomi memberikan pengaruh terhadap peningkatan kebutuhan dasar air.

Dikenal dua kategori fasilitas penyediaan air minum, yaitu :

a. Fasilitas Perpipaan, terdiri dari :

- Sambungan Rumah (SR)

- Sambungan Halaman

- Sambungan Umum

b. Fasilitas Non perpipaan, terdiri dari :

Sumur umum, kendaraan tangki air (water tank), mata air.

Yang perlu diketahui juga adalah jumlah kebutuhan rata-rata air bersih per orang per hari, dimana dibedakan atas kategori kota. Berikut ini standar yang dikeluarkan oleh Dirjen Cipta Karya Departemen PU :

Tabel 1. Kebutuhan Air Bersih Berdasarkan Kategori Kota Dan Jumlah Penduduknya.

\begin{tabular}{|l|c|c|c|c|}
\hline \multirow{2}{*}{$\begin{array}{c}\text { Kategori } \\
\text { kota }\end{array}$} & $\begin{array}{c}\text { Jumlah } \\
\text { Penduduk }\end{array}$ & $\begin{array}{c}\text { Penyediaa } \\
\text { n air } \\
\text { (liter/org/ } \\
\text { hari) }\end{array}$ & $\begin{array}{c}\text { Kehilanga } \\
\text { n Air } \\
(\%)\end{array}$ \\
\cline { 3 - 4 } & SR & HU & \\
\hline \hline $\begin{array}{c}\text { Metropol } \\
\text { itan }\end{array}$ & $>1.000 .000$ & 190 & 30 & 20 \\
\hline Besar & $\begin{array}{c}500.000- \\
1.000 .00 \\
0\end{array}$ & 170 & 30 & 20 \\
\hline Sedang & $\begin{array}{c}100.000- \\
500.000\end{array}$ & 150 & 30 & 20 \\
\hline Kecil & $\begin{array}{c}20.000- \\
100.000\end{array}$ & 130 & 30 & 20 \\
\hline IKK & $<20.000$ & 100 & 30 & 20 \\
\hline
\end{tabular}

Sumber: J uknis Perencanaan Sistem Penyediaan Air Minum Perkotaan, (vol. I1), 1998. 


\subsubsection{Kebutuhan Air Non Domestik}

Kebutuhan air non domestik merupakan tahap selanjutnya dalam perhitungan kebutuhan air bersih. Besaran pemakaiannya ditentukan oleh jumlah konsumen non domestik yang terdiri dari fasilitas-fasilitas sebagaimana dijelaskan pada halaman sebelumnya.

Sebagaimana penjelasan sebelumnya bahwa ada beberapa faktor yang dapat menentukan perkembangan jumlah fasilitas tersebut, yaitu pertambahan penduduk, jenis dan perluasan fasilitas serta perkembangan sosial ekonomi.

Perhitungan proyeksi fasilitas dapat dilakukan dengan pendekatan perbandingan jumlah penduduk, yaitu :

$\frac{\text { Pendudultahurke }-\mathrm{n}}{\text { Pendudultahunawal }}=\frac{\text { Fasilita\$ahurke }-\mathrm{n}}{\text { Fasilita\$ahumawal }}$ (7)

Sumber:J uknis Perencanaan Sistem Penyediaan Air Minum Perkotaan, (vol. 1l), 1998.

\subsection{KAPASITAS PRODUKSI}

Penentuan besaran kebutuhan air menurut Al-layla, dkk (1980) mengacu pada kebutuhan air harian maksimum ( $Q$ max.day) serta kebutuhan air jam maksimum ( $Q$ hour.max) dengan referensi kebutuhan air ratarata.

a. Kebutuhan air rata-rata harian $\left(Q_{\text {av.day }}\right)$ Adalah jumlah air yang diperlukan untuk pemenuhan kebutuhan domestik, non domestik dan kehilangan air.

b. Kebutuhan air harian maksimum (Q max.day)

Merupakan jumlah air terbanyak yang diperlukan pada satu hari dalam kurun satu tahun berdasarkan nilai $\mathrm{Q}$ rata-rata harian. Diperlukan faktor fluktuasi kebutuhan harian maksimum dalam perhitungannya.

$Q_{\text {max.day }}=f \times Q_{\text {av.day }}$

Dimana :

$\mathrm{f}=$ Faktor harian maksimum $(1<\mathrm{f}$ max.hour $<1,5$ )

$\mathrm{Q}_{\text {av.day }}=$ Kebutuhan air harian maksimum (ltr/dtk)

c. Kebutuhan air jam maksimum (Q max.hour) Adalah jumlah air terbesar yang diperlukan pada jam-jam tertentu. Faktor fluktuasi kebutuhan jam maksimum ( $F$ max.hour) diperlukan dalam perhitungannya.

$Q_{\text {max.hour }}=f \times Q_{\text {max.hour. }}$

Dimana :

$\mathrm{f}=$ Faktor fluktuasi jam maksimum $(1,5-2,5)$

$\mathrm{Q}_{\text {max.day }}=$ Kebutuhan air harian maksimum

$\mathrm{Q}_{\text {max.hour }}=$ Kebutuhan air jam maksimum (ltr/jam).

Banyak faktor yang mempengaruhi fluktuasi pemakaian air jam per jam, dan untuk mendapatkan data fluktuasi ini diperlukan survey (penelitian) terhadap aktivitas atau kebutuhan air konsumen.

Selain penentuan kapasitas produksi pada unit pengolahan, maka perlu diperhitungkan lagi faktor-faktor lain yang berpengaruh terhadap perencanaan unit pengolahan.

d. Kehilangan Air

Yaitu selisih antara jumlah air yang diproduksi di unit pengolahan dengan jumlah air yang di konsumsi (jaringan distribusi). Berdasarkan kenyataan dilapangan, kejadian akan kehilangan air ini selalu terjadi. Adapun bentuk kehilangan dapat bersifat teknis dan non teknis.

Terdapat 3 macam pengertian menyangkut istilah kehilangan air, yaitu :

1) Kehilangan air rencana

Kehilangan yang disebabkan oleh pengaruh operasional dan pemeliharaan unit pengolahan.

2) Kehilangan air percuma

Meliputi segala aspek penggunaan fasilitas penyediaan air bersih dan pengelolaannya. Kehilangan ini dapat dibagi dua, yaitu :

- Leakage; merupakan kehilangan air percuma pada komponen fasilitas yang disebabkan oleh kurangnya pengendalian pengelola.

- Wastage; adalah kehilangan air yang terjadi pada tingkatan konsumen.

3) Kehilangan air insidentil

Jika kehilangan air yang terjadi akibat hal-hal yang berada diluar kemampuan manusia dan bersifat spontan seperti bencana dan sebagainya.

Namun secara umum dalam melakukan perencanaan unit 
pengolahan air bersih, nilai kehilangan yang terjadi baik khilangan air percuma dan insidentil sudah masuk dalam perhitungan. Besarnya nilai kehilangan air tersebut berkisar antara 15 - 25 \% dari total kebutuhan air bersih baik domestik maupun non domestik.

e. Kebutuhan air untuk pemadam kebakaran

Untuk penentuan besar pemakaian untuk pemadam kebakaran di Indonesia belum ada standarisasinya, sehingga cenderung bersifat subyektif tergantung dari kondisi dan kebijakan setempat. Menurut Allayla, dkk (1980) dapat diambil antara 10 $-25 \%$ dari kebutuhan harian maksimum[4].

\subsection{INSTALASI PENGOLAHAN AIR BERSIH (IPAB)}

Instalasi Pengolahan Air Bersih adalah suatu gabungan beberapa tahapan unit bangunan pengolahan air baku yang diambil dari sumbernya. Pada bangunan ini terjadi proses teknis untuk mengubah kualitas air yang diperoleh menjadi lebih baik sesuai dengan standar yang ditentukan.

Dalam proses pengolahan air bersih umumnya dikenal dengan dua cara yaitu pengolahan lengkap (complette treatment procces) dan pengolahan sebagian (partial treatment procces)

Dalam perencanaan bangunan pengolahan air bersih, penentuan lokasi bangunan adalah termasuk hal yang penting diperhatikan. Beberapa hal yang perlu diperhatikan sebelum memilih lokasi bangunan adalah [3]:

a) Tanah / lahan yang tersedia harus cukup luas sehingga masih memungkinkan untuk diperluas dikemudian hari.

b) Kondisi tanah harus cukup stabil sebagai tempat diman bangunan akan dibuat. Jika dukungan kondisi tanah kurang memenuhi, harus direncanakan model Keberadaannya tidak sampai mengganggu lingkungan sekitar.

c) Aspek keamanan juga menjadi hal penting yang harus dipertimbangkan, mengingat jenis bangunan adalah vital.

d) Transportasi sebagai akses untuk mobilisasi bahan kimia dan operator. e) Sedapat mungkin relatif dekat dengan sumber air baku dan konsumen.

f) Jika sistim distribusinya secara gravitasi, maka pemilihan level permukaan tanah harus cukup tinggi.

g) konstruksi yang aman.

\section{HASIL STUDY \\ 3.1 CURAH HUJ AN RENCANA}

\subsubsection{Curah Hujan Rencana Berbagai Periode Ulang}

Perhitungan curah hujan rencana pada Daerah Aliran Sungai Sungai Grindulu dibagi menjadi beberapa sub DAS dengan titik tinjauan pada beberapa anak sungai Sungai Grindulu dibagian hilirnya. Data curah hujan yang digunakan berasal dari beberapa stasiun curah hujan yang berpengaruh seperti tersebut diatas, dengan perbandingan luas das menggunakan metode Poligon Thiessen.

Analisis sebaran yang digunakan pada perhitungan ini menggunakan metode Log Pearson Tipe III dan Gumbel. Namun setelah dilaksanakan uji Chi Square dan Smirnov Kolmogorov, hasil yang relevan dan akan digunakan untuk perencanaan debit banjir adalah metode Gumbel seperti yang disajikan pada tabel berikut ini.

\subsubsection{Distribusi Hujan J am-J aman}

Untuk menentukan lama durasi hujan tidak ada pencatatan hidrograf jam-jaman dari banjir yang pernah terjadi di DAS Sungai Grindulu untuk dapat digunakan sebagai parameter perencanaan. Oleh karena itu durasi optimum hujan rencana ditentukan berdasarkan studi terdahulu "Feasibility Study Rencana Pengendalian Banjir Sungai Grindulu, 1985”

Durasi optimum selama 6 jam, dengan distribusi jam-jaman 55\%, 14,3\%, 10\%, $8 \%$, 6,7\% dan 5,9\%. Intensitas hujan tertinggi terjadi pada jam pertama.

\subsection{HIDROGRAF BANJ IR}

Dalam studi ini perhitungan hidrograf banjir dilakukan dengan menggunakan metode hidrograf satuan sintetik Nakayasu dengan pembanding metode lainnya yang setara. Untuk menentukan hidrograf satuan di suatu Daerah Aliran Sungai (DAS), dipergunakan metode Nakayasu dan Snyder modifikasi[6]. 


\subsubsection{Hidrograf Satuan Sintetik Nakayasu} Untuk menentukan hidrograf di suatu daerah aliran pengaliran sungai akan dipakai metode Hidrograf Satuan Sintetik Nakayasu. Dalam perhitungan banjir rencana dengan hidrograf Satuan Sintetik Nakayasu, maka perlu diketahui karakteristik atau parameter daerah alirannya. Karakteristik Daerah Aliran Sungai yang perlu diketahui adalah :

* Tenggang waktu dari permulaan hujan sampai puncak hidrograf (time to peak magnitude).

* Tenggang waktu dari titik berat hujan sampai titik berat hidrograf.

* Tenggang waktu hidrograf (time base of hydrograph)

* Panjang alur sungai utama yang terpanjang (lenght of the longest channel).

* Koefisien Pengaliran.

Persamaan dari Hidrograf Satuan

Sintetik Nakayasu adalah sebagai

berikut :

$Q p=\frac{C \cdot A \cdot \text { Ro }}{3,6 \cdot\left(0,3 T p+T_{0,3}\right)}$

Dimana :

$\mathrm{Qp}=$ Debit puncak banjir $\left(\mathrm{m}^{3} / \mathrm{dt}\right)$

Ro = Hujan Satuan ( $\mathrm{mm}$ )

$\mathrm{Tp}=$ Tenggang waktu dari permulaan hujan sampai puncak banjir (jam)

$\mathrm{T}_{0,3}=$ Waktu yang diperlukan oleh penurunan debit dari debit puncak sampai menjadi $30 \%$ dari debit puncak.

Untuk menentukan $\mathrm{Tp}$ dan $\mathrm{T}_{0,3}$ digunakan persamaan :

$\mathrm{Tp}=\mathrm{Tg}+0,8 \mathrm{tr}$

$\mathrm{T}_{0,3}=\propto . \mathrm{Tg}$

Tg adalah time lag, yaitu waktu antara hujan sampai dengan debit puncak banjir (jam).

Tg dihitung berdasarkan atas :

1) Sungai dengan panjang lebih dari $15 \mathrm{~km}$ $\mathrm{Tg}=0,40+0,058 \mathrm{~L}$

2) Sungai dengan panjang kurang dari 15 $\mathrm{km}$

$\operatorname{Tg}=0,21+0,70 \mathrm{~L}$

$\propto=$ parameter hidrograf

$\operatorname{tr}=$ satuan waktu $(1$ jam $)$
Persamaan hidrograf satuan adalah :

1). Pada Kurva Naik :

$$
\begin{aligned}
& \mathbf{0} \leq \mathbf{t} \leq \mathbf{T p} \\
& \mathrm{Qt}=\mathrm{Qmax}(\mathrm{t} / \mathrm{Tp})^{2,4}
\end{aligned}
$$

2). Pada Kurva Turun :

$$
T p \leq t \leq\left(T p+T_{0,3}\right)
$$

Qt $=\mathrm{Qmax} .0,3^{[(\mathrm{t}-\mathrm{Tp}) / \mathrm{T} 0,3]}$

$\left(T p+T_{0,3}\right) \leq t \leq\left(T p+T_{0,3}+T_{0,3}{ }^{2}\right)$

$\mathrm{Qt}=\mathrm{Qmax}$. 0,3[( $\mathrm{t}-\mathrm{Tp}+0,5 \cdot \mathrm{T} 0,3) /(1,5 \cdot \mathrm{T} 0,3)]$

$t \geq\left(\mathrm{Tp}+\mathrm{T}_{0,3}+\mathbf{1 , 5}, \mathrm{T}_{0,3}\right)$

$\mathrm{Qt}=\mathrm{Qmax}$. 0,3[(t-Tp+1,5.T0,3)/(2.T0,3)]

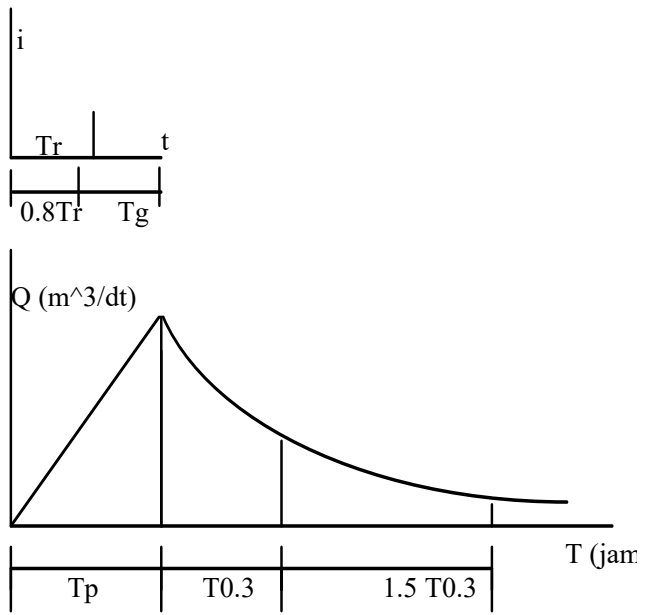

Gambar 1. Hidrograf Satuan Nakayasu

\subsubsection{Hidrograf Banj ir Rancangan}

Dari hasil perhitungan hidrograf satuan akan didapat suatu bentuk satuan hidrograf yang mendekati dengan sifat aliran banjir sungai yang ada, yang selanjutnya hidrograf banjir untuk berbagai kala ulang dapat dihitung dengan mempergunakan persamaanpersamaan yang ada pada salah satu metode yang sesuai tersebut di atas.

Hidrograf banjir untuk berbagai kala ulang dapat dihitung dengan persamaan sebagai berikut :

$\mathrm{Q}_{\mathrm{k}}=\mathrm{U}_{1} R_{\mathrm{i}}+\mathrm{U}_{2} R_{\mathrm{i}-1}+\mathrm{U}_{3} R_{\mathrm{i}-2}+\ldots . .+\mathrm{U}_{\mathrm{n}} R_{\mathrm{i}-\mathrm{n}+1}+\mathrm{B}_{\mathrm{f}}$

Dimana :

$\mathrm{Q}_{\mathrm{k}}=$ Ordinat hidrograf banjir pada jam ke $\mathrm{k}$.

$U_{n}=$ Ordinat hidrograf satuan.

$R_{i}=$ Hujan netto (efektif) pada jam ke I.

$\mathrm{B}_{\mathrm{f}}=$ Aliran dasar (base flow). 
J urnal APLIKASI

Volume 8, Nomor 2, Agustus 2010 ISSN.1907-753X

Rumus di atas dalam bentuk tabel dapat disajikan sebagai berikut :

\begin{tabular}{|c|c|c|c|c|c|c|}
\hline $\begin{array}{c}\text { Hidrograf } \\
\text { Satuan } \\
\left(\mathrm{m}^{3} / \mathrm{dt} / \mathrm{mm}\right)\end{array}$ & $\begin{array}{c}\mathrm{R} 1 \\
(\mathrm{~mm})\end{array}$ & $\begin{array}{c}\mathrm{R} 2 \\
(\mathrm{~mm})\end{array}$ & $\mathrm{Rn}$ & $\begin{array}{l}\mathrm{Rm} \\
(\mathrm{mm})\end{array}$ & $\begin{array}{l}\text { Aliran } \\
\text { Dasar } \\
\left(\mathrm{m}^{3} / \mathrm{dt}\right)\end{array}$ & $\begin{array}{l}\text { Debit } \\
\left(\mathrm{m}^{3} / \mathrm{dt}\right)\end{array}$ \\
\hline Q1 & $\mathrm{q} 1 . \mathrm{R} 1$ & - & - & - & B & Q1 \\
\hline Q1 & $\mathrm{q} 2 . \mathrm{R} 1$ & Q1.R2 & - & - & B & Q2 \\
\hline Q3 & q3.R1 & Q2.R2 & $\cdots$ & - & B & Q3 \\
\hline Q4 & q4.R1 & Q3.R2 & $\cdots$ & q1. Rm & B & Q4 \\
\hline Q5 & q5.R1 & Q4.R2 & $\cdots$ & q2. Rm & B & Q5 \\
\hline$\ldots$ & $\ldots$ & Q5.R2 & $\cdots$ & q3. Rm & B & Qn \\
\hline \multirow[t]{4}{*}{ Qn } & qn. R1 & $\ldots$ & $\cdots$ & q4. Rm & B & $Q n+1$ \\
\hline & & qn.R2 & $\cdots$ & q5. Rm & B & $Q n+2$ \\
\hline & & & $\cdots$ & $\ldots$ & B & $Q n+3$ \\
\hline & & & $\ldots$ & qn.Rm & B & $\mathrm{Qn}+\mathrm{m}-1$ \\
\hline
\end{tabular}

\subsubsection{Hidrograf Banjir Sub DAS Grindulu}

Hasil perhitungan hidrograf banjir untuk DAS Grindulu disajikan dalam bentuk tabel 2 dan gambar 2 sebagai berikut :

Tabel 2. Hidrograf Banjir Sungai DAS Grindulu[5]

\begin{tabular}{|c|c|c|c|c|c|c|c|}
\hline $\begin{array}{c}\text { T } \\
\text { ( Jam ) }\end{array}$ & $\begin{array}{c}Q_{2} \\
\text { (m3/det) }\end{array}$ & $\begin{array}{c}Q_{5} \\
\text { (m3/det) }\end{array}$ & $\begin{array}{c}\mathbf{Q}_{10} \\
\text { (m3/det) }\end{array}$ & $\begin{array}{c}Q_{25} \\
\text { (m3/det) }\end{array}$ & $\begin{array}{c}Q_{50} \\
\text { (m3/det) }\end{array}$ & $\begin{array}{c}Q_{100} \\
\text { (m3/det) }\end{array}$ & $\begin{array}{c}\mathbf{Q}_{200} \\
\text { (m3/det) }\end{array}$ \\
\hline 0 & 0.700 & 0.700 & 0.700 & 0.700 & 0.700 & 0.700 & 0.700 \\
\hline 1 & 4.454 & 5.702 & 6.529 & 7.573 & 8.347 & 9.116 & 9.882 \\
\hline 2 & 21.490 & 28.402 & 32.978 & 38.760 & 43.049 & 47.307 & 51.549 \\
\hline 3 & 58.968 & 78.338 & 91.163 & 107.367 & 119.389 & 131.321 & 143.210 \\
\hline 4 & 123.069 & 163.748 & 190.682 & 224.652 & 249.958 & 275.018 & 299.986 \\
\hline 5 & 219.446 & 292.165 & 340.311 & 400.826 & 446.274 & 491.070 & 535.703 \\
\hline 6 & 353.393 & 470.641 & 548.269 & 645.512 & 719.117 & 791.344 & 863.307 \\
\hline 7 & 529.574 & 705.391 & 821.797 & 967.199 & 1077.988 & 1186.294 & 1294.205 \\
\hline 8 & 649.610 & 865.331 & 1008.157 & 1185.752 & 1322.495 & 1455.383 & 1587.786 \\
\hline 9 & 672.587 & 895.947 & 1043.831 & 1226.243 & 1369.299 & 1506.892 & 1643.984 \\
\hline 10 & 671.242 & 894.154 & 1041.741 & 1221.791 & 1366.557 & 1503.875 & 1640.692 \\
\hline 11 & 652.713 & 869.466 & 1012.975 & 1187.082 & 1328.816 & 1462.339 & 1595.376 \\
\hline 12 & 619.372 & 825.041 & 961.211 & 1126.709 & 1260.901 & 1387.597 & 1513.830 \\
\hline 13 & 571.766 & 761.609 & 887.302 & 1040.162 & 1163.931 & 1280.878 & 1397.397 \\
\hline 14 & 519.307 & 691.710 & 805.857 & 944.675 & 1057.074 & 1163.278 & 1269.094 \\
\hline 15 & 471.667 & 628.233 & 731.894 & 857.960 & 960.034 & 1056.481 & 1152.577 \\
\hline 16 & 428.403 & 570.587 & 664.725 & 779.210 & 871.908 & 959.495 & 1046.764 \\
\hline 17 & 389.113 & 518.236 & 603.726 & 707.695 & 791.877 & 871.419 & 950.670 \\
\hline 18 & 353.433 & 470.694 & 548.331 & 642.749 & 719.198 & 791.433 & 863.404 \\
\hline 19 & 321.030 & 427.519 & 498.025 & 583.769 & 653.195 & 718.795 & 784.155 \\
\hline 20 & 291.643 & 388.363 & 452.400 & 530.278 & 593.335 & 652.916 & 712.280 \\
\hline
\end{tabular}

J urnal APLIKASI: Media Informasi \& Komunikasi Aplikasi Teknik Sipil Terkini 


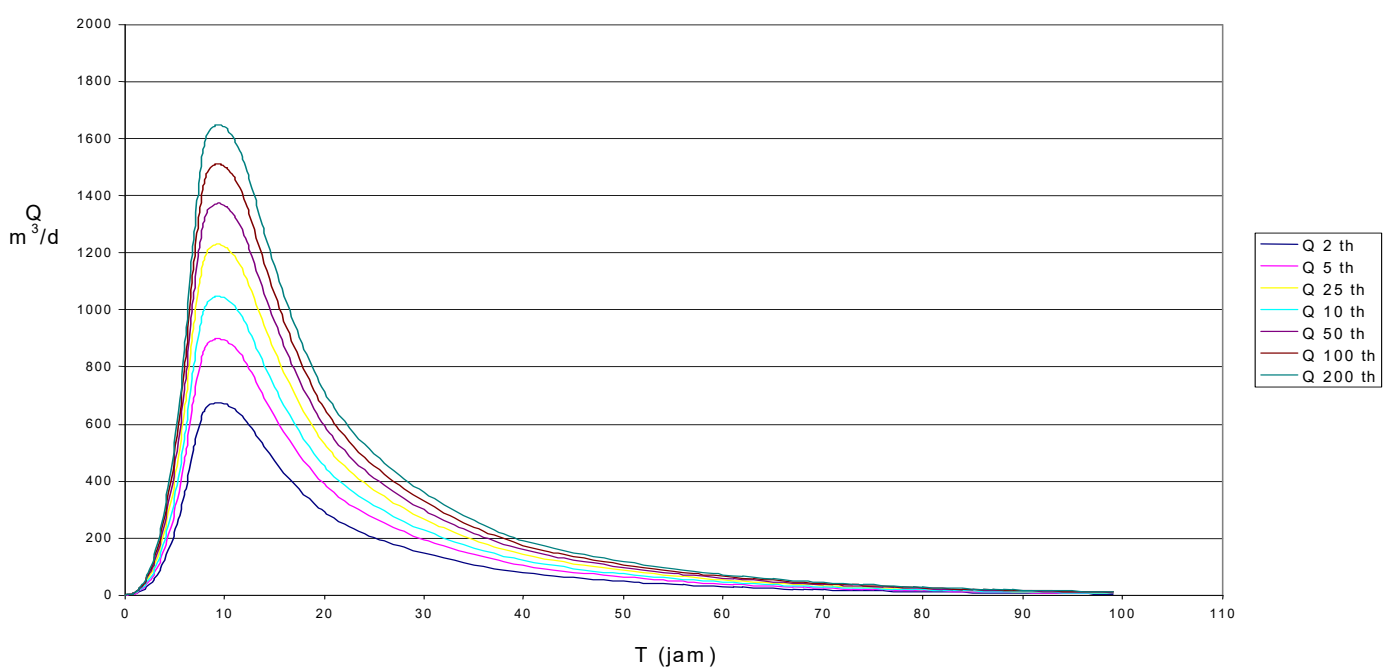

Gambar 2. Grafik Hidrograf Satuan Sintetik Nakayasu DAS Grindulu [7]

\subsection{DEBIT BANJ IR RENCANA}

\subsubsection{Koefisien Pengaliran}

Pada saat hujan turun sebagian air akan meresap ke dalam tanah dan sebagian lagi akan menjadi limpasan permukaan. Koefisien limpasan / pengaliran adalah variabel untuk menentukan besarnya limpasan permukaan tersebut dimana penentuannnya didasarkan pada kondisi daerah pengaliran dan karakteristik hujan yang jatuh di daerah tersebut. Karakteristik DAS Sungai Grindulu dibagian hulu dapat dikategorikan daerah pegunungan, tetapi sebaliknya pada bagian tengah dan hilir kondisi lahan sebagian besar tidak dilindungi oleh hutan / tanaman yang dapat menahan limpasan air permukaan dan sungai berada di daerah dataran rendah.

Dalam menentukan besarnya koefisien aliran daerah studi menggunakan perumusan dari Dr. Kawakami sebagai berikut :

\subsubsection{Debit Banjir Rencana Berbagai Periode Ulang}

Hasil perhitungan debit banjir rencana dengan metode hidrograf Nakayasu yang selanjutnya akan digunakan untuk perencanaan adalah sebagai berikut :
Tabel 3. Debit Banjir Rencana Berbagai Periode Ulang [8]

\begin{tabular}{|c|c|}
\hline \multirow{2}{*}{$\begin{array}{c}\text { Kala Ulang } \\
(\text { Th })\end{array}$} & Q Banjir Rencana $\left(\mathrm{m}^{3} / \mathrm{dt}\right)$ \\
\cline { 2 - 2 } 2 & Sungai Grindulu \\
\hline \hline 5 & 673 \\
10 & 896 \\
25 & 1044 \\
50 & 1226 \\
100 & 1369 \\
200 & 1507 \\
\hline
\end{tabular}

Sumber : Hasil Analisa, 2009

\subsection{DEBIT ANDALAN}

Debit andalan merupakan debit sungai yang dapat diandalkan selalu tersedia di sungai sepanjang tahun yang dapat digunakan untuk memenuhi kebutuhan air bersih. Untuk menghitung besarnya debit andalan dapat digunakan data debit sungai Grindulu yang tercatat dalam waktu cukup lama. Apabila tidak tersedia data pencatatan debit sungai dalam jangka lama maka dapat dilakukan pengukuran sesaat terutama pada musim kemarau kondisi paling kritis.

Untuk analisis debit andalan di DAS Grindulu ini menggunakan data 16 tahun yaitu dari tahun 1990 sampai dengan tahun 2006. Berikut adalah hasil perhitungan 
J urnal APLIKASI

ISSN. 1907-753X

debit andalan bulanan per tahun di DAS Grindulu.

Tabel 4. Debit Andalan Bulanan Per Tahun DAS Grindulu Kota Pacitan

\begin{tabular}{|c|c|c|c|c|c|c|c|c|c|c|c|c|}
\hline \multirow{2}{*}{ Tahun } & \multicolumn{12}{|c|}{ Debit Andalan ( $\left.\mathrm{m}^{3} / \mathrm{det}\right)$} \\
\hline & Jan & Feb & Mar & Apr & Mei & Juni & Juli & Agt & Sep & Okt & Nop & Des \\
\hline 1990 & 16.50 & 15.40 & 14.90 & 6.30 & 3.40 & 3.00 & 2.20 & 1.20 & 0.50 & 0.30 & 0.30 & 3.00 \\
\hline 1991 & 26.10 & 25.50 & 9.40 & 19.20 & 2.18 & 1.07 & 0.72 & 0.76 & 0.98 & 1.34 & 2.06 & 6.28 \\
\hline 1992 & 18.50 & 37.40 & 12.90 & 15.90 & 6.93 & 0.80 & 0.44 & 0.32 & 1.82 & 5.30 & 8.88 & 10.40 \\
\hline 1993 & 20.70 & 4.84 & 8.80 & 5.32 & 2.06 & 2.18 & 2.30 & 1.82 & 0.64 & 0.48 & 1.07 & 15.00 \\
\hline 1994 & 13.00 & 13.00 & 22.20 & 5.80 & 2.51 & 1.61 & 1.16 & 0.56 & 0.36 & 0.28 & 0.40 & 0.76 \\
\hline 1995 & 10.60 & 39.90 & 35.50 & 13.30 & 6.98 & 6.58 & 3.05 & 1.18 & 0.27 & 1.93 & 2.16 & 6.61 \\
\hline 1996 & 44.10 & 33.00 & 17.70 & 8.93 & 3.32 & 1.87 & 1.08 & 0.72 & 0.31 & 1.72 & 19.40 & 22.70 \\
\hline 1997 & 11.50 & 11.40 & 5.04 & 5.34 & 14.10 & 2.03 & 0.78 & 0.48 & 0.25 & 0.36 & 0.49 & 3.16 \\
\hline 1998 & 3.88 & 49.30 & 87.10 & 58.20 & 20.60 & 20.90 & 45.70 & 18.70 & 16.30 & 26.90 & 56.40 & 43.50 \\
\hline 1999 & 41.50 & 24.20 & 22.10 & 18.30 & 10.20 & 5.70 & 3.92 & 2.27 & 1.30 & 2.62 & 5.96 & 17.30 \\
\hline 2000 & 17.70 & 32.50 & 23.90 & 25.20 & 11.10 & 5.28 & 3.10 & 1.47 & 0.49 & 29.20 & 30.50 & 7.08 \\
\hline 2001 & 26.60 & 2.68 & 9.38 & 12.00 & 7.86 & 10.70 & 7.51 & 4.10 & 2.90 & 3.52 & 7.51 & 1.23 \\
\hline 2002 & 0.57 & 32.83 & 31.85 & 37.50 & 15.20 & 9.40 & 7.13 & 4.86 & 3.62 & 0.74 & 2.33 & 12.42 \\
\hline 2003 & 8.28 & 37.44 & 24.96 & 9.19 & 5.02 & 2.51 & 1.45 & 1.08 & 0.80 & 0.80 & 1.19 & 17.35 \\
\hline 2004 & 74.26 & 108.74 & 110.60 & 25.06 & 12.04 & 17.23 & 9.23 & 7.90 & 7.07 & 5.73 & 8.43 & 140.58 \\
\hline 2005 & 64.78 & 61.42 & 57.60 & 42.76 & 27.93 & 26.53 & 24.18 & 6.72 & 1.05 & 2.95 & 4.27 & 10.22 \\
\hline 2006 & 63.12 & 62.59 & 52.46 & 60.01 & 45.14 & 12.82 & 7.66 & 5.15 & 4.10 & 1.71 & 1.71 & 1.90 \\
\hline Jumlah & 461.69 & 592.14 & 546.39 & 368.31 & 196.57 & 130.21 & 121.61 & 59.29 & 42.76 & 85.88 & 153.06 & 319.49 \\
\hline Rerata & 27.16 & 34.83 & 32.14 & 21.67 & 11.56 & 7.66 & 7.15 & 3.49 & 2.52 & 5.05 & 9.00 & 18.79 \\
\hline
\end{tabular}

Sumber : Hasil Analisa, 2009

Berikut adalah tabel hubungan antara debit andalan rata-rata dengan debit pengambilan.

Tabel 5. Hubungan Q. Andalan dengan Q. Pengambilan

\begin{tabular}{||c|c|c|}
\hline Bulan & $\begin{array}{c}\text { Debit Andalan Rata-Rata } \\
\mathrm{m}^{3} / \text { det }\end{array}$ & $\begin{array}{c}\text { Kebutuhan Pengambilan } \\
\mathrm{m}^{3} / \mathrm{det}\end{array}$ \\
\hline \hline Jan & 27.16 & 0.12 \\
\hline Feb & 34.83 & 0.12 \\
\hline Mar & 32.14 & 0.12 \\
\hline Apr & 21.67 & 0.12 \\
\hline Mei & 11.56 & 0.12 \\
\hline Jun & 7.66 & 0.12 \\
\hline Jul & 7.15 & 0.12 \\
\hline Agt & 3.49 & 0.12 \\
\hline Sep & 2.52 & 0.12 \\
\hline Okt & 5.05 & 0.12 \\
\hline Nop & 9.00 & 0.12 \\
\hline Des & 18.79 & 0.12 \\
\hline \hline
\end{tabular}

Sumber : Hasil Analisa, 2009

J urnal APLIKASI: Media Informasi \& Komunikasi Aplikasi Teknik Sipil Terkini 


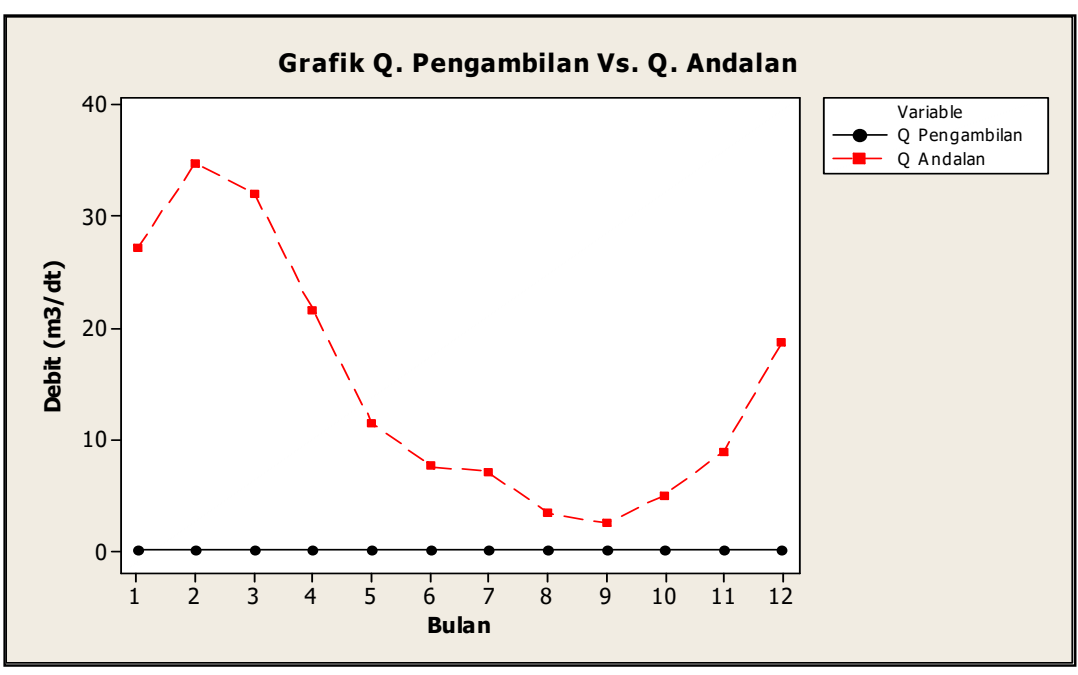

Dari hasil perhitungan dan grafik dapat diketahui bahwa debit andalan yang tersedia melebihi debit kebutuhan pengambilan sebesar $120 \mathrm{lt} / \mathrm{dt}$ atau $0,12 \mathrm{~m}^{3} / \mathrm{dt}$, sehingga dapat disimpulkan bahwa kebutuhan air untuk memenuhi kebutuhan air bersih dalam sistem IPAM di Kota Pacitan sangat layak dan memenuhi serta tidak perlu dibuatkannya reservoar sebagai tampungan sementara sehingga air dapat diambil dari sungai secara kontinyu[8].

\subsection{PROYEKSI KAPASITAS PRODUKSI}

Tabel 6. Jumlah Pelanggan PDAM Kota Pacitan Tahun 1997 - 2007

\begin{tabular}{|c|c|c|c|c|}
\hline No. & Tahun & $\begin{array}{c}\text { Jumlah } \\
\text { Pelanggan (Unit) }\end{array}$ & $\begin{array}{c}\text { Pertumbuhan } \\
\text { Jumlah Pelanggan }\end{array}$ & $\begin{array}{c}\text { \% Pertumbuhan } \\
\text { Jumlah Pelanggan }\end{array}$ \\
\hline \hline 1 & 1997 & 5,737 & 54 & 0.94 \\
\hline 2 & 1998 & 5,791 & 133 & 2.30 \\
\hline 3 & 1999 & 5,924 & 493 & 8.32 \\
\hline 4 & 2000 & 6,417 & 238 & 3.71 \\
\hline 5 & 2001 & 6,655 & 64 & 0.96 \\
\hline 6 & 2002 & 6,719 & 60 & 0.89 \\
\hline 7 & 2003 & 6,779 & $(579)$ & -8.54 \\
\hline 8 & 2004 & 6,200 & 688 & 11.10 \\
\hline 9 & 2005 & 6,888 & 232 & 3.37 \\
\hline 10 & 2006 & 7,120 & 1,219 & 17.12 \\
\hline 11 & 2007 & 8,339 & - & - \\
\hline \hline \multicolumn{2}{|c|}{ Jumlah } & 72,569 & 2,602 & 40.17 \\
\hline \multicolumn{2}{|c|}{ Rerata } & 6,597 & 260 & 4.02 \\
\hline
\end{tabular}

Sumber : BPS Pacitan Diolah, 2009

Dari tabel jumlah pelanggan PDAM dapat dijelaskan bahwa jumlah pelanggan PDAM Kota Pacitan memiliki nilai rata-rata laju pertumbuhannya sebesar 260 unit per tahunnya, dengan persentase sebesar $4,02 \%$ per tahunnya.

Sedangkan untuk hasil model persamaan analisis regresi antara jumlah pelanggan dengan data penduduk dapat dilihat sebagai berikut. 


\section{ISSN. 1907-753X}

\subsection{PROYEKSI J UMLAH PRODUKSI AIR PDAM}

Data jumlah produksi air PDAM ini diambil dari tahun 1997 sampai dengan 2007 dengan nilai rata-rata pertumbuhan jumlah produksi sebesar $122.489 \mathrm{~m}^{3}$ per tahunnya, dengan persentase laju pertumbuhan sebesar $16,74 \%$ per tahunnya. Data ini akan diproyeksikan terhadap jumlah penduduk kota Pacitan tapi terlebih dahulu diregresikan untuk mendapatkan model persamaan dengan bantuan MINITAB 14.

Tabel 7. Jumlah Produksi Air PDAM Kota Pacitan Tahun 1997 - 2007

\begin{tabular}{|c|c|c|c|c|}
\multirow{2}{*}{ No. } & Tahun & $\begin{array}{c}\text { Jumlah } \\
\text { Produksi }\left(M^{3}\right)\end{array}$ & $\begin{array}{c}\text { Pertumbuhan } \\
\text { Jumlah Produksi }\end{array}$ & $\begin{array}{c}\text { \% Pertumbuhan } \\
\text { Jumlah Produksi }\end{array}$ \\
\hline \hline 1 & 1997 & 619,936 & $(90,173)$ & -14.55 \\
\cline { 5 - 5 } & 1998 & 529,763 & 152,997 & 28.88 \\
\hline 3 & 1999 & 682,760 & 125,187 & 18.34 \\
\hline 4 & 2000 & 807,947 & 41,945 & 5.19 \\
\hline 5 & 2001 & 849,892 & $(202,604)$ & -23.84 \\
\hline 6 & 2002 & 647,288 & 683,143 & 105.54 \\
\hline 7 & 2003 & $1,330,431$ & $(55,160)$ & -4.15 \\
\hline 8 & 2004 & $1,275,271$ & $(232,664)$ & -18.24 \\
\hline 9 & 2005 & $1,042,607$ & 118,875 & 11.40 \\
\hline 10 & 2006 & $1,161,482$ & 683,340 & 58.83 \\
\hline 11 & 2007 & $1,844,822$ & - & 167.41 \\
\hline \hline \multicolumn{2}{|c|}{ Jumlah } & $10,792,199$ & $1,224,886$ & 16.74 \\
\hline \multicolumn{2}{|c|}{ Rerata } & 981,109 & 122,489 & \\
\hline
\end{tabular}

Sumber : BPS Pacitan Diolah, 2009

Berikut adalah hasil model persamaan analisis regresi antara jumlah produksi air PDAM dengan data penduduk Kota Pacitan.

Dimana :

$\mathrm{Pn}=$ Jumlah Penduduk 
Tabel 8. Estimasi Proyeksi Kebutuhan Air, Pelanggan, Produksi Air, Dan Nilai Produksi PDAM Terhadap Jumlah Penduduk Kota Pacitan

\begin{tabular}{|c|c|c|c|c|c|}
\hline \multirow[t]{2}{*}{ Tahun } & $\begin{array}{l}\text { Proyeksi } \Sigma \\
\text { Penduduk } \\
\text { (jiwa) }\end{array}$ & $\begin{array}{l}\text { Keb. Air Total } \\
\text { (lt/dt) }\end{array}$ & $\begin{array}{c}\Sigma \text { Pelanggan PDAM } \\
\text { (Unit) }\end{array}$ & $\begin{array}{c}\Sigma \text { Produksi PDAM } \\
\left(\mathrm{m}^{3}\right)\end{array}$ & $\begin{array}{l}\text { Nilai Produksi PDAM } \\
\text { (Rp.) }\end{array}$ \\
\hline & $P n=P o(1+r)^{n} \cdot \alpha$ & $\begin{array}{l}\text { Yair }=706+ \\
0.00116 \mathrm{Pn}\end{array}$ & $\begin{array}{c}\text { Y Plgn }=-18780+ \\
0.404 \mathrm{Pn}\end{array}$ & $\begin{array}{c}\text { Y Prod }=-11977907 \\
+206 \mathrm{Pn}\end{array}$ & $\begin{array}{c}Y \text { Cost }=-3.42 \mathrm{E}+10+ \\
563248 \mathrm{Pn}\end{array}$ \\
\hline 1998 & 61,075 & 776.85 & 5,894 & 603,543 & $200,371,600$ \\
\hline 1999 & 61,495 & 777.33 & 6,064 & 690,063 & $436,935,760$ \\
\hline 2000 & 61,899 & 777.80 & 6,227 & 773,287 & $664,487,952$ \\
\hline 2001 & 62,098 & 778.03 & 6,308 & 814,281 & $776,574,304$ \\
\hline 2002 & 62,480 & 778.48 & 6,462 & 892,973 & $991,735,040$ \\
\hline 2003 & 62,663 & 778.69 & 6,536 & 930,671 & $1,094,809,424$ \\
\hline 2004 & 63,013 & 779.10 & 6,677 & $1,002,771$ & $1,291,946,224$ \\
\hline 2005 & 64,766 & 781.13 & 7,385 & $1,363,889$ & $2,279,319,968$ \\
\hline 2006 & 64,774 & 781.14 & 7,389 & $1,365,537$ & $2,283,825,952$ \\
\hline 2007 & 65,344 & 781.80 & 7,619 & $1,482,957$ & $2,604,877,312$ \\
\hline 2008 & 65,464 & 781.94 & 7,667 & $1,507,677$ & $2,672,467,072$ \\
\hline 2009 & 64,142 & 780.40 & 7,133 & $1,235,294$ & $1,927,714,183$ \\
\hline 2010 & 64,590 & 780.92 & 7,314 & $1,327,663$ & $2,180,271,192$ \\
\hline 2011 & 65,042 & 781.45 & 7,497 & $1,420,678$ & $2,434,593,744$ \\
\hline 2012 & 65,496 & 781.98 & 7,681 & $1,514,343$ & $2,690,694,181$ \\
\hline 2013 & 65,954 & 782.51 & 7,866 & $1,608,663$ & $2,948,584,933$ \\
\hline 2014 & 66,415 & 783.04 & 8,052 & $1,703,642$ & $3,208,278,514$ \\
\hline 2015 & 66,880 & 783.58 & 8,239 & $1,799,286$ & $3,469,787,529$ \\
\hline 2016 & 67,347 & 784.12 & 8,428 & $1,895,598$ & $3,733,124,667$ \\
\hline 2017 & 67,818 & 784.67 & 8,618 & $1,992,583$ & $3,998,302,708$ \\
\hline 2018 & 68,292 & 785.22 & 8,810 & $2,090,246$ & $4,265,334,523$ \\
\hline 2019 & 68,769 & 785.77 & 9,003 & $2,188,592$ & $4,534,233,069$ \\
\hline 2020 & 69,250 & 786.33 & 9,197 & $2,287,625$ & $4,805,011,397$ \\
\hline 2021 & 69,734 & 786.89 & 9,393 & $2,387,351$ & $5,077,682,647$ \\
\hline 2022 & 70,222 & 787.46 & 9,590 & $2,487,773$ & $5,352,260,053$ \\
\hline 2023 & 70,713 & 788.03 & 9,788 & $2,588,898$ & $5,628,756,939$ \\
\hline 2024 & 71,207 & 788.60 & 9,988 & $2,690,730$ & $5,907,186,725$ \\
\hline 2025 & 71,705 & 789.18 & 10,189 & $2,793,274$ & $6,187,562,922$ \\
\hline 2026 & 72,206 & 789.76 & 10,391 & $2,896,534$ & $6,469,899,137$ \\
\hline 2027 & 72,711 & 790.34 & 10,595 & $3,000,516$ & $6,754,209,072$ \\
\hline 2028 & 73,219 & 790.93 & 10,801 & $3,105,226$ & $7,040,506,524$ \\
\hline 2029 & 73,731 & 791.53 & 11,007 & $3,210,667$ & $7,328,805,388$ \\
\hline 2030 & 74,246 & 792.13 & 11,216 & $3,316,845$ & $7,619,119,655$ \\
\hline 2031 & 74,765 & 792.73 & 11,425 & $3,423,766$ & $7,911,463,414$ \\
\hline 2032 & 75,288 & 793.33 & 11,636 & $3,531,434$ & $8,205,850,853$ \\
\hline 2033 & 75,814 & 793.94 & 11,849 & $3,639,855$ & $8,502,296,257$ \\
\hline 2034 & 76,344 & 794.56 & 12,063 & $3,749,033$ & $8,800,814,014$ \\
\hline 2035 & 76,878 & 795.18 & 12,279 & $3,858,975$ & $9,101,418,611$ \\
\hline 2036 & 77,415 & 795.80 & 12,496 & $3,969,686$ & $9,404,124,636$ \\
\hline 2037 & 77,957 & 796.43 & 12,715 & $4,081,170$ & $9,708,946,780$ \\
\hline 2038 & 78,502 & 797.06 & 12,935 & $4,193,434$ & $10,015,899,835$ \\
\hline
\end{tabular}

Sumber : Hasil Analisis Data, 2009 


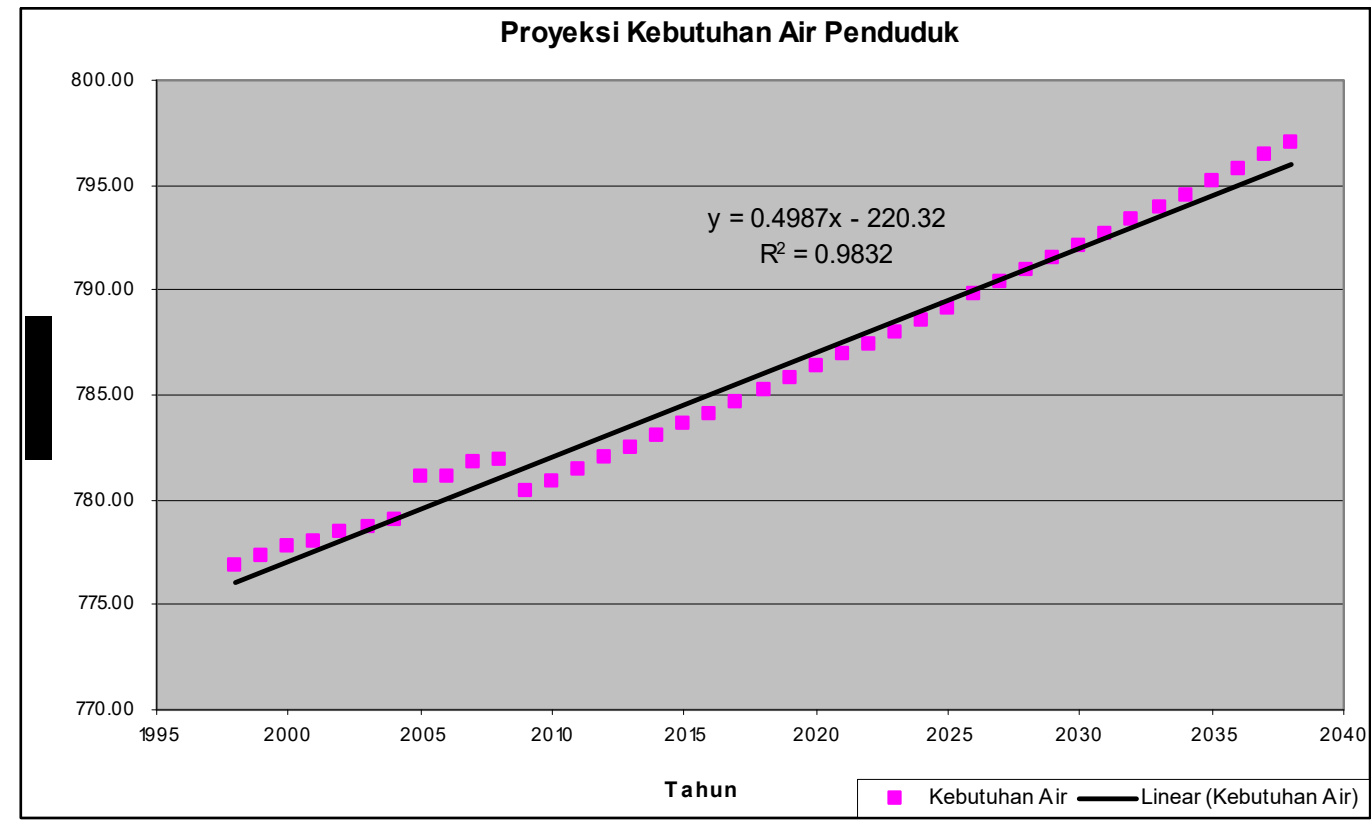

Sumber : Hasil Analisa, 2009

Gambar 3. Grafik Proyeksi Kebutuhan Air Penduduk Terhadap Jumlah Penduduk Dari Hasil Model Persamaan Regresi

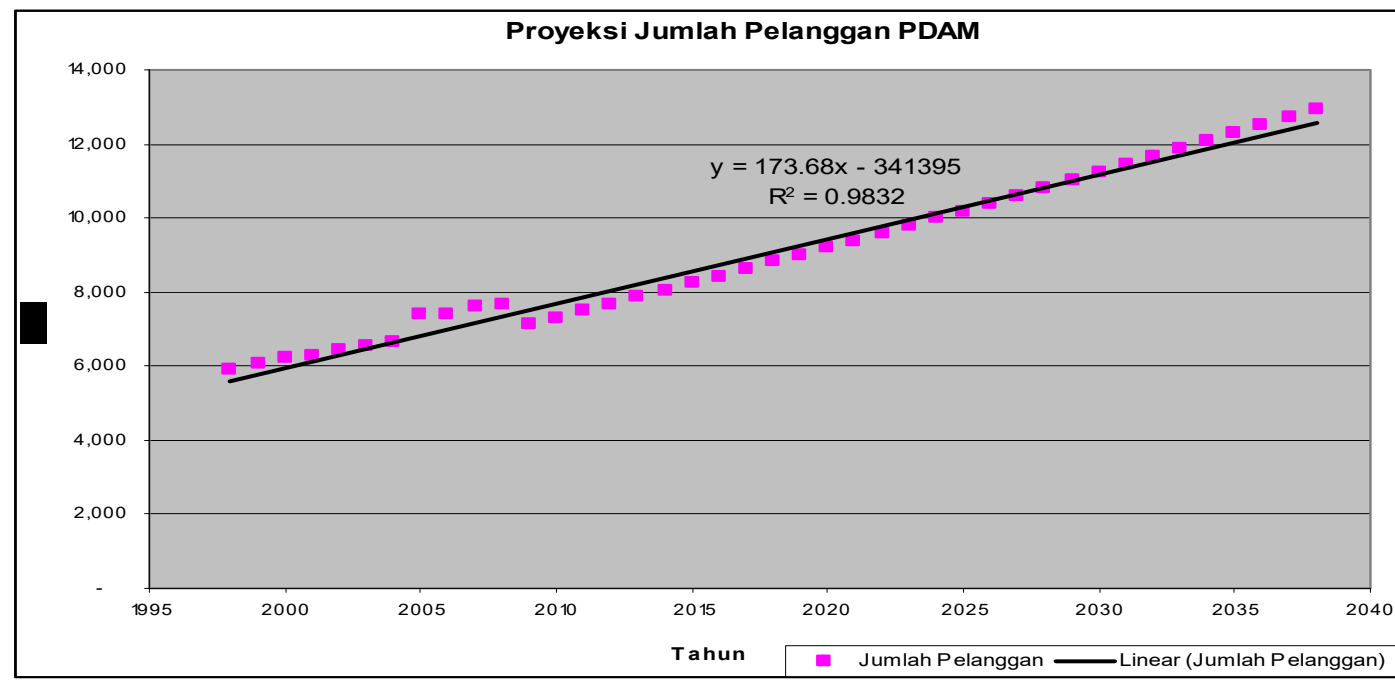

Sumber : Hasil Analisa, 2009

Gambar 4. Grafik Proyeksi Jumlah Pelanggan Terhadap Jumlah Penduduk Dari Hasil Model Persamaan Regresi 


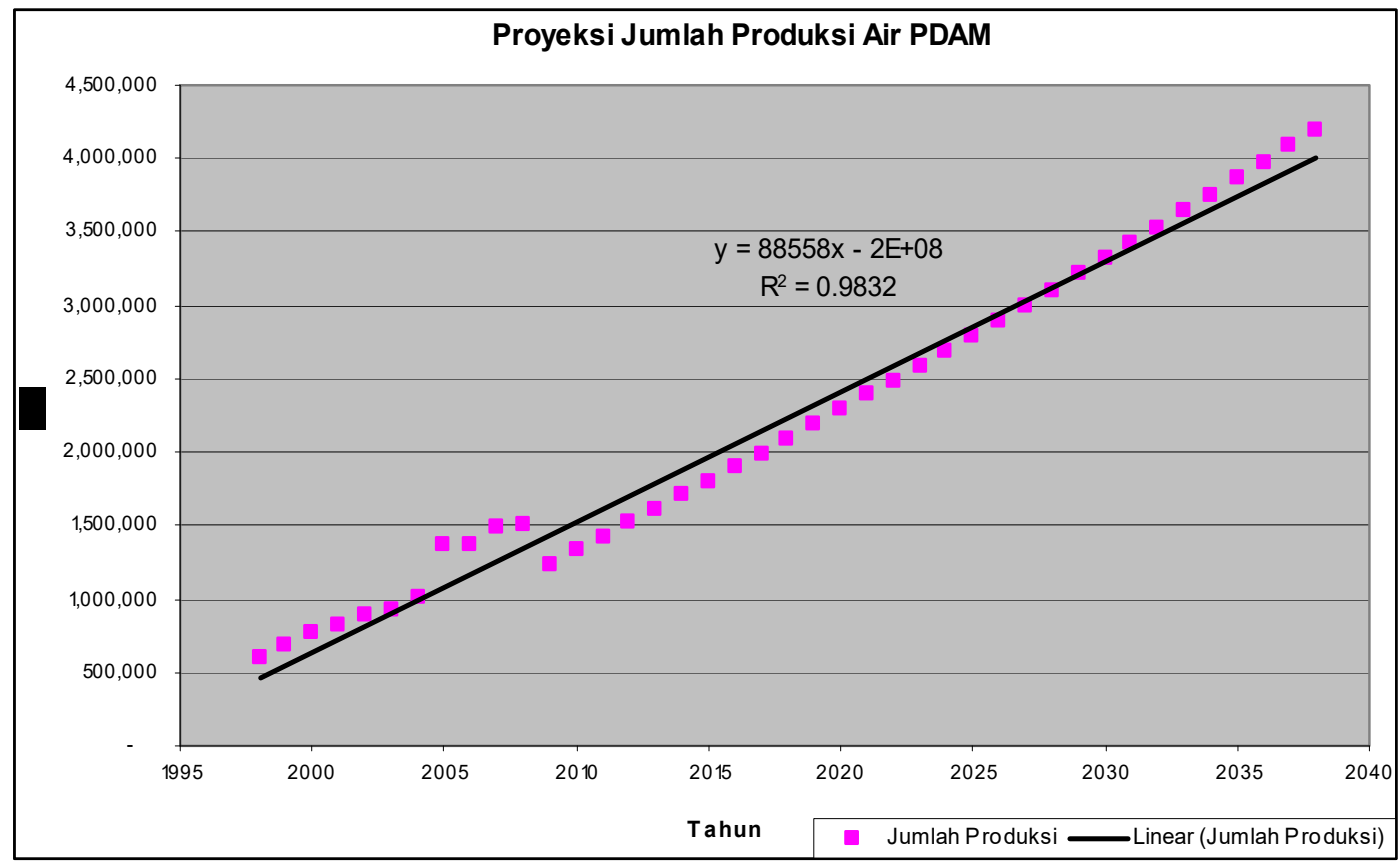

Sumber : Hasil Analisa, 2009

Gambar 5. Grafik Proyeksi Jumlah Produksi Air PDAM Terhadap Jumlah

\subsection{DEBIT UPRATING}

Untuk mencari debit kebutuhan air uprating Kota Pacitan untuk 30 tahun mendatang yaitu pada tahun 2038 dipakai beberapa alternatif metode yaitu sebagai berikut :

a. Berdasarkan Pendekatan Proyeksi Jumlah Penduduk:

$>$ Jumlah penduduk $=78.502$ jiwa

$>$ Kebutuhan air total $=797,06 \mathrm{lt} / \mathrm{det}$

$>$ Debit uprating $\quad=797,06-60 \mathrm{lt} / \mathrm{det}$ $=737,06 \mathrm{lt} / \mathrm{det}$

b. Berdasarkan Pendekatan Proyeksi Jumlah Pelanggan :

$>$ Jumlah pelanggan

> Dengan asumsi 1 unit melayani 4 penduduk

> Jumlah penduduk yang dilayani

$>$ Kebutuhan air total sesuai dengan persamaan fungsi yaitu :

$=706+0,00116 . P n$

$=706+0,00116 \times 51.740$

$=706+60,018$

$=766,018 \mathrm{lt} / \mathrm{det}$

$>$ Debituprating $=766,018-60 \mathrm{lt} / \mathrm{det}=706,018 \mathrm{lt} / \mathrm{det}$

c. Berdasarkan Pendekatan Jumlah Pelanggan Baru / Pelanggan Tunggu :
Jumlah pelanggan tunggu=1.778 jiwa

$>$ Kebutuhan air total sesuai dengan persamaan fungsi yaitu :

$=706+0,00116 . P n$

$=706+0,00116 \times 1.778$

$=706+2,062$

$=708,062 \mathrm{lt} / \mathrm{det}$

$>$ Debit uprating $=708,062-60 \mathrm{lt} / \mathrm{det}$ $=648,062 \mathrm{lt} / \mathrm{det}$

Dari hasil proyeksi persentase sambungan rumah pada 30 tahun mendatang didapatkan :

$>$ Jumlah sambungan 30 tahun $=12.935$ Samabungaiq35 unit

> Proyeksi jumlah penduduk 30 tahun $=78.502$ jiwa

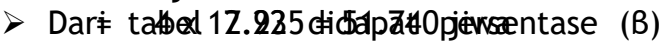
$=17,84 \%$

> Sambungan Pelanggan Eksisting $=17,84 \% \times 78.502=14.005$ Sambungan

$>$ Jumlah Pelanggan Sambungan Baru $=1.778$ Sambungan

$>$ Sambungan Total = Sambungan Eksisting + Calon Sambungan Baru $=14.005+1.778=15.783$ Sambungan

$>$ Debit Produksi Real $=60 \mathrm{lt} / \mathrm{det}$

$>$ Distribusi Real $=40$ lt $/$ det 
Jumlah Pelanggan Real (Th. 2007) $=8.339$ Sambungan

Distribusi Real Per Sambungan=40 / 8.339 $=0,004797 \mathrm{lt} / \mathrm{det} / \mathrm{samb}$

> Debit Distribusi Untuk 30 Tahun=0,004797 $\mathrm{x} 15.783$

$=75,707 \mathrm{lt} / \mathrm{det}$

> Debit Uprating Distribusi 30

Tahun=75,707 - $40 \mathrm{lt} / \mathrm{det}$

$=35,707 \mathrm{lt} / \mathrm{det}$

> Debit Uprating Terpasang $=35,707 \quad x$ $(60 / 40)$

$=53,56 \mathrm{lt} / \mathrm{det}$

$\approx 60 \mathrm{lt} / \mathrm{det}$

Dari hasil keempat alternatif metode pendekatan diatas, maka hasil debit uprating yang diambil untuk perencanaan adalah dari analisa metode pendekatan persentase sambungan rumah yaitu sebesar $60 \mathrm{lt} / \mathrm{dt}$.

\section{KESIMPULAN}

1. Pertumbuhan jumlah penduduk Kota Pacitan adalah sebesar $0,70 \%$, dengan metode Geometrik didapatkan pearson correlation (a) sebesar 0,973.

2. Kebutuhan air penduduk pada proyeksi 30 tahun mendatang adalah sebesar :

> Kebutuhan air penduduk 100\% terlayani sebesar 797,63 lt/dt

$>$ Kebutuhan air penduduk 75\% terlayani sebesar 774,81 lt/dt

$>$ Kebutuhan air penduduk $60 \%$ terlayani sebesar 761,12 lt/dt

3. Kebutuhan debit pengambilan di intake adalah sebesar $120 \mathrm{lt} / \mathrm{dt}$.

4. Persamaan model regresi pada proyeksi kapasitas produksi untuk 30 tahun mendatang adalah sebagai berikut :
a. $Y_{\text {air }}=706+0,00116 \mathrm{Pn}$
b. $Y_{\text {pelanggan }}=-18780+0,404 \mathrm{Pn}$
c. $Y_{\text {produksi }}=-11977907+206 \mathrm{Pn}$
d. $Y_{\text {cost }}=-3,42 E+10+563248 P n$

5. Analisis debit uprating didekati dengan cara proyeksi presentase sambungan rumah real yaitu sebesar $60 \mathrm{lt} / \mathrm{dt}$, dengan persamaan model regresi sebagai berikut :
a. $Y_{\text {pelanggan }}=-18780+0,404 \mathrm{Pn}$
b. $Y_{S R}=-18,9+0,000468 P n$

6. Permasalahan penting pada bangunan intake antara lain :

a. Bangunan pengambilan tidak berfungsi karena jauh dari aliran sungai, sehingga sumuran tidak terisi air.

b. Pada musim penghujan debit aliran Grindulu besar tetapi sangat keruh, sehingga tidak dilakukan pengambilan air selama 5 bulan dan selanjutnya suplay air bersih di kota Pacitan sepenuhnya diambil dari sumber air Jaten dan sumber air Slare.

c. Pipa distribusi dari IPAM pada saat ini muncul diatas dasar Sungai Grindulu sehingga rawan putus dihantam banjir, batuan maupun pohon yang hanyut di sungai.

d. Dasar sungai disekitar bangunan pengambilan merupakan tanah sedimen sehingga aliran mudah berpindah-pindah.

7. Debit andalan rata-rata terbesar adalah $34,83 \mathrm{~m}^{3} /$ det terjadi pada bulan Februari saat musim hujan, sedangkan debit andalan rata-rata yang paling kecil sebesar $2,52 \mathrm{~m}^{3} /$ det terjadi pada bulan September saat musim kemarau, sedangkan pengambilan direncanakan secara konstan sebesar $0,12 \mathrm{~m}^{3} /$ det. Mengingat debit andalan terkecil dimusim kemarau masih jauh lebih besar dibandingkan debit pengambilan maka sistim pengambilan dapat dilakukan secara langsung dan tidak memerlukan waduk / reservoir.

8. Diketahui debit andalan sumber air Sungai Grindulu masih mampu untuk memenuhi kebutuhan air penduduk sampai 30 tahun kedepan yaitu rata-rata sebesar $0,79 \mathrm{~m}^{3} / \mathrm{dt}$.

\section{DAFTAR PUSTAKA}

Acuan yang dipakai untuk penulisan artikel ini antara lain:

[1]. 2005, “Basin Water Resources Management Plan (BWRMP) WS Grindulu", Tim Perencana SDA Kabupaten Pacitan \& Good Governance in Water Resources Management (GGWRM), Pacitan. 
[2]. 2005, "Pola Pengelolaan Sumber Daya Air WS Grindulu Kabupaten Pacitan", Tim Perencana SDA Kabupaten Pacitan \& Good Governance in Water Resources Management 2005, "Progres River Infastructure Management Grindulu River", Satuan Tugas Pengelolaan Sumber Daya Air Koordinator Pemeliharaan Prasarana, Dinas Permukiman dan Prasarana Wilayah, Pacitan (GGWRM), Pacitan.

[3]. 2002, "Totorials to Watershed Modeling System", Environmental Modelling Research Laboratory, Brigham Young University.

[4]. 1996, "User's Manual to DUfLOW ver. 2.04", International Institute for Infrastructural, Hydraulic and Environmental Engineering, IHE Delft, The Netherlands.

[5]. 1985, "Feasibility Study Rencana Pengendalian Banjir Kali Grindulu", Institut Teknologi Sepuluh Nopember, Fakultas Teknik Sipil, Surabaya.

[6]. 1985, "Hidrologi Untuk Pengairan", Sosrodarsono, Suyono dan Kensaku Takeda Erlangga, Bandung

[7]. 1984, "Master Plan Kali Grindulu", Institut Teknologi Sepuluh Nopember, Fakultas Teknik Sipil, Surabaya.

[8]. 1979, "Studi Kali Grindulu Kabupetan Pacitan", Universitas Gadjah Mada, Yogyakarta. 